\title{
最近の不織布研究動向
}

\section{Recent Development in Studies of Nonwoven Fabrics}

渡邊明

1.はじめに

我が国の不織布産業は、1960 年に当時の呉羽紡績(株)(現 東洋紡績(株)）が米国より乾式不織布製造設備 1 系列を購入 し、関連会社「リットンセンター(侏)(現呉羽テック(株)」で 生産したのが始まりであるとされている。一方、ニードル パンチ機が最初にわが国に輸入されたのは 1961 年 12 月で あった”。我が国のニードルパンチ機は 1962 年 3 月寿工業 (株によって作られたのが最初であっだ”。の後、不織布 は目覚しい発展を遂げ、今では宇宙用材料にも欠かせない 材料となっている。

\section{2. 不織布の生産量および研究の分類}

まず最初に、日本における 1999 年度の不織布生産高の 製法別と用途別分類をそれぞれ図 1、図 2 に示す4。製法 別では、ニードルパンチ式が $30 \%$ で最も多く、次いでケ ミカルボンド式、スパンボンド式と続く。用途別では、産 業用が $27 \%$ と最も多く、医療・衛生用と続く。衣料用は わずか $4 \%$ にすぎない。

次に、最近の不織布に関する研究の分類と各分野の報文 数を表 1 に示す。表 1 は、最近 3 年間('99/11〜 $02 / 10) に$ 記載されたJICSTファイルの不織布分野の文献を分類し たものである。まず“報告”と“論文”に大別した。論文 をさらに分野別に分類するに当って、ジオテキスタイル(土 木)関連は当然工学に属するが、論文数がきわめて多く特 殊分野として別分類にした。士学関連の“研究論文”をさ らに“基礎”と“灾用”に分けた。“基礎”とは、不織布 そのものを研究詨象とし、その構造解析および力学特性を 中心とした論文、および構造と物性 (力学、実用)との関係 について研究した論文を指す。一方、“応用”とは、不織 布の特異的性質を生かし、具体的に用途・製品を視野に入 れて、製品の一部に利用した研究を指す。いずれの分類に

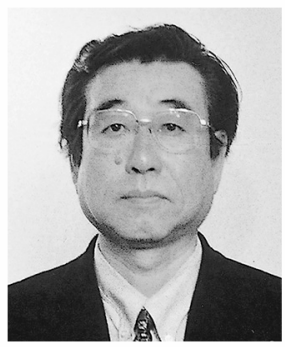

AKIRA WATANABE

岐皁大学工学部応用化学科

助教授 工学博士

厂 501-1193 岐皋市柳戸 $1-1$

Tel : 058-293-2625 Fax : 058-293-2625

E-mail : watanabe@apchem.gifu-u.ac.jp

〈専門〉繊維工学、高分子材料

〈趣味〉水泳、テニス、魚釣り

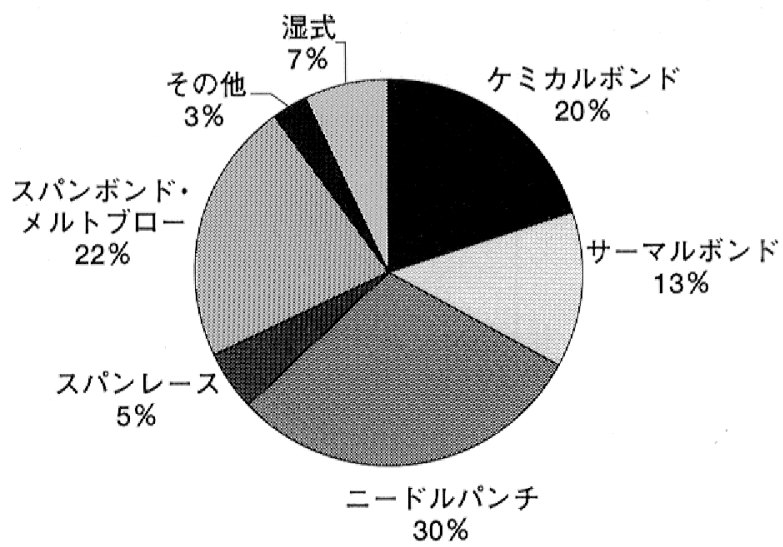

図1日本の不織布生産高(製法別)

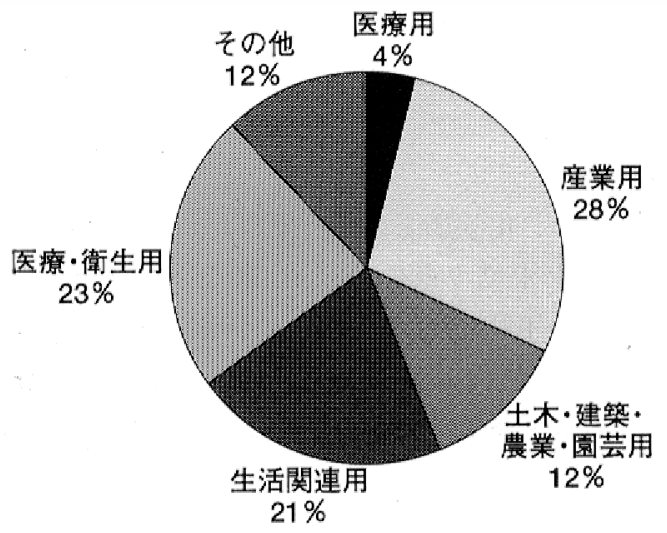

図 2 日本の不織布生産高(用途別)

おいても、明確に区別することが困難な報文がきわめて数 多くあったが、あえて勇断した。

この分類より、最近 3 年間で約 1600 件の不織布の“報 告”および“論文”があり、それぞれ同程度の数である。

“報告”の内、“解説と市場調査”で約半分 (46\%)を占め る。次いで、“技術開発・新加工法” が、約 $20 \%$ と続く。 評価・検討および不織布を利用した新製品の紹介もそれぞ れ同程度 (約 10\%) 報告されている。

一方、“研究論文”では，“工学関連”が約 60\%(ジオを 含めると約 80\%) を占める。工学関連の “基礎” と“応用” の論文数の割合は、前者が約 $40 \%$ 、後者約 $60 \%$ である。 これらの論文の内、著者が現在興味をもっているニードル パンチ不織布に関する論文数は、約 $30 \%$ である。この割 合は、偶然にしろ図 1 のニードルパンチ不織布の製法別生 産量の割合と一致している。 


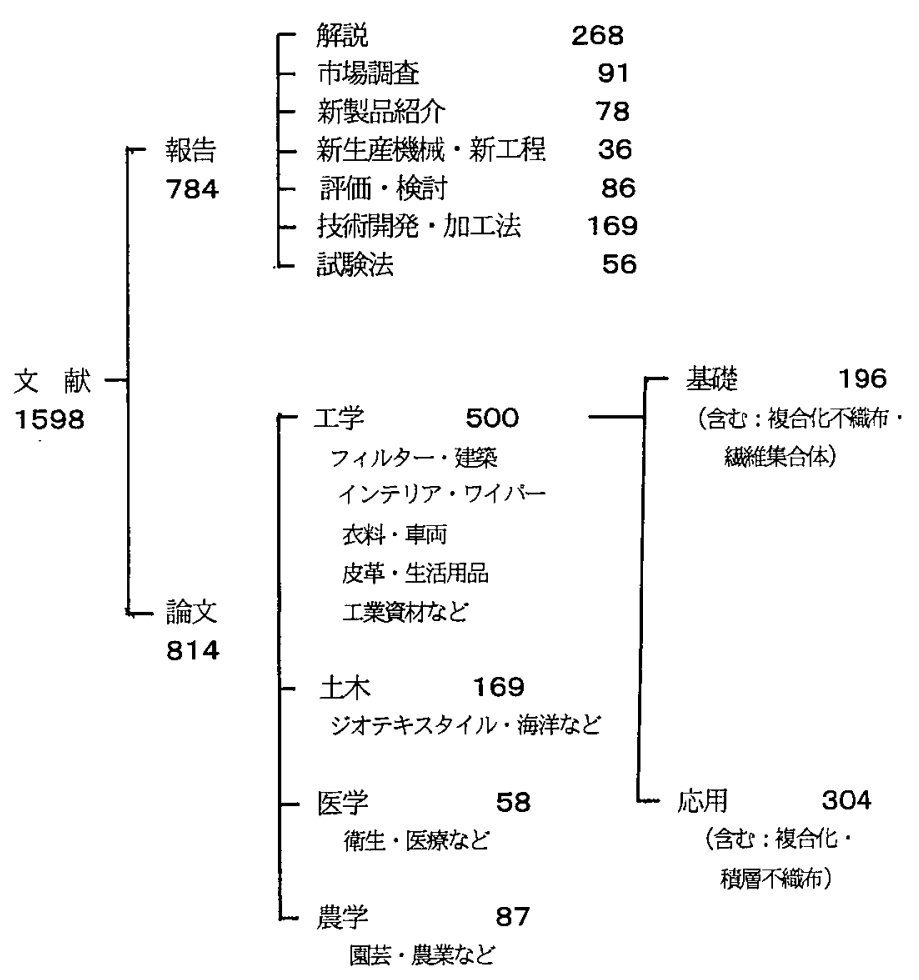

\section{3. 最近の研究動向}

表 10 工学分野から抜粋した論文の内、ニードルパンチ 不織布に関する研究論文を中心に特性別に紹介する。

\section{1 力学特性}

Ganguly らは、化学加工ジュート(TJ) およびジュートと ポリプロピレン混紡ウェブを、 $80,120,160 \mathrm{Pene} / \mathrm{m}^{2}$ でニー ドルパンチした不織布について、曲げ剛性、密度、引張挙 動、応力緩和、繰返し荷重に対するパンチ密度の影㗽を検 討した。混紡不織布は TJ 不織布に比べて、引張強度、弾 性率は全てのパンチ密度で高いが、応力緩和による応力低 下は著しく大きかっだ。

渡邉らは、アラミド系繊維(ノーメックス)のニードルパ ンチ不織布に $200^{\circ} \mathrm{C}$ 以上の高温で $2 \mathrm{MPa}$ の高圧下で熱圧 縮疲学を繰り返し( 1 サイクル 60 分で最高 100 回)与元、 その後の不織布の圧縮挙動に及ぼす針の形状の影響を研究 し、圧縮回復特性と針のスロートの断面積との関係を詳細 に考察した。スロートの断面積が大きいほど厚さ方向に配 列する繊維数が多くなり圧縮回復が良くなった ${ }^{5.6 .6}$ 。また、 疲労温度の方が疲労圧力より不織布の圧縮挙動により大き な影響を与えることを明らかにした ${ }^{7.8)}$ 。一方、引張強度は、 疲労温度が $210^{\circ} \mathrm{C}$ を超えると減少し、 $260^{\circ} \mathrm{C}$ では約 $20 \%$ 減少した。この結果は、耐熱性アラミド繊維の熱分解温度 は $370^{\circ} \mathrm{C}$ であるにもかかわらず、熱と压力を同時に加える と、それ以下の温度でも繊維の劣化が生ずることを示唆し ている9”。さらに、引張特性に及ぼす針の形状とパンチ密 度の影響についても研究し、スロートにキックアップがあ り、さらにパンチ密度が $600 \mathrm{Pene} / \mathrm{m}^{2}$ 以上になると、針は 繊維を切断し、引張強度が減少することを示した100。

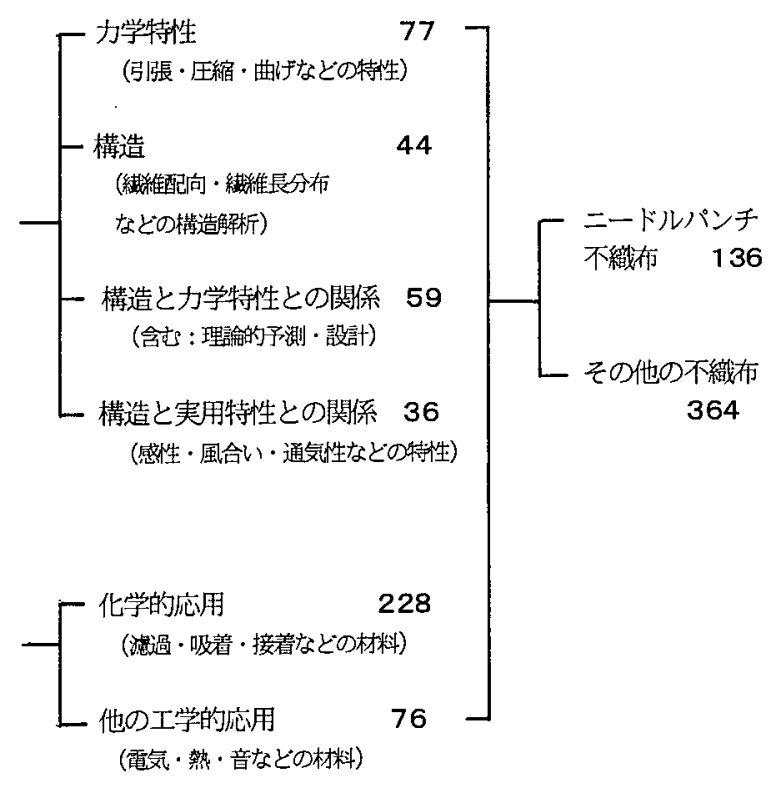

Debnath らは、黄麻をべースとしたニードルパンチ不織 布の強度、破断伸度、構造異方性、圧縮厚さに及ぼす重量、 針密度、混合率(黄麻/ポリプロピレン)の影響を研究し、 パンチ密度 $200 \mathrm{punch} / \mathrm{cm}^{2}$ で構造が強固となり最適パンチ 密度であると結論した"11。

Lee らは、不織布挿入型士 45 アングルプライハイブリッ ド複合材料の剛性を予測するため、ポアソン比を考慮した 二次元複合則を提案し、実駼值に近い計算値を得た ${ }^{22}$ 。

Gamguly らは、100\%の黄麻抢よび黄麻とポリプロピレ ン混紡のニードルパンチ不織布について、パンチ密度、針 浸透深さ，黄麻の繊維長、ポリプロピレン繊維の混率が力 学特性に及ぼす影響を研究し、ポリプロピレン混紡の方が よりかさ高で強く、ソフトである。さらに、ポリプロピレ ン繊維をランダムに積層する方が機械方向の不織布の引張 特性打よび曲げ特性が良くなると報告している(3)。

Leeらは、各種針穴パンチ密度の不織布の力学的性質に 及ぼす紪維構造変化の影響を研究し、引張強度、破壊勒性 はパンチ密度の増加とともに増加するが、曲げ、衝撃、疲 労および磿耗特性はパンチ密度の増加とともに減少すると 述べているい"

Wizemann は、パンチ密度が高いほどニードルフェルト の安定性が良くなること、バーブやスロートは最も重要な 部分で、繊維を引掛けて交絡させ縦・横・斜め方向の強度 を増加させることなどを報告している ${ }^{15) 。}$

\section{2 構造}

Pourdehyhimi らは、画像解析の技法を応用して、ナイ ロン捲縮繊維ウェプのニードルパンチ、ポリプロピレン繊 維のスパンボンドおよびスパンボンドーメルトブロー、ポ 
リエステル繊維のスパンボンド等の不織布中の繊維配向特 性を求めた16)。また、彼らは、カードウェブやスパンボン ド不織布を用いて、不織布の各画像から背景への最低距離 を2回画像走査で求める距離変換の画像解析法で、不織布 繊維の直径の分布状態を測定した ${ }^{17}$ 。

Krucinska らは、不織布の繊維配列を画像で測定するた め、円偏光顕微鏡観察技法を応用した画像処理システムを 開発した。また、統計的手法による繊維配列の計算結果と の整合性の評洒によって、本ソフトウェアの有効性を検証 している ${ }^{181}$ 。

金子らは、パンチング中の繊維切断に及ぼす針の挿入深 さ、および針の形状の影響を、針のキックアップに着目し て検討した ${ }^{19)}$ 。

Kang らは、ニードルパンチ不織布は繊維の絡み合いに より三次元構造をとるが、その繊維配向度とパンチ密度と の関係を画像解析システムにより解析した ${ }^{20 !}$ 。

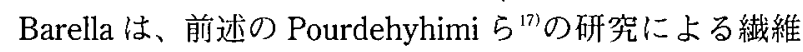
直径の統計的分布が対数正規モデルに明瞭に従うことを示 した21)。

\section{3 構造と物性 (力学、実用特性) との関係}

Thorr らは、画像解析ソフトウェアと機械的動力計と光 センサとを組み合わせた装置を開発し、ポリエステルスパ ンボンド不織布の引張りによる不織布の構造変化を追跡し た。各種のパラメータに数学的解析を行うことにより、複 雑な力学的挙動(降伏点など)に関する基本的情報を解明し た2!'。

永田らは、マイクロ波を用いた繊維配向測定法により， アラミド紙およびそのプレプレグの㵶維配向を測定し，ア ラミド繊維の線膨張係数の長軸方向と短軸方向の比と配向 度 (MOR)とは強い相関関係があることを示した ${ }^{23) 。 ~}$

Adanur らは、有限要素法による不織布の応力ひずみ挙 動を予測するコンピュータモデルをさらに発展させ、不織 布の引張挙動(特に曲線の形状)は繊維ウェブの捲縮(カー ル)分布の影響を大きく受けることを示した。さらに、引 張変形中の不織布の横収縮を解析するための数值法を提案 し、不織布の力学的性質に及ぼす繊維配向諸特性の影響を 実験的および理論的に解析した ${ }^{24)}$ 。

森沢らは、スパンレース不織布では、高圧水ジェット (WJ)で纎維を交絡させるため，WJ が通過した孔が残る特 殊な構造になることに着目し、不織布およびWJの条件を 変えて、細孔径分布および官能特性(柔らかさ、風合い)に 及ぼす影響を研究した

$\operatorname{Kim}$ らは、点接着不織布の引張試験による構造変化を リアルタイムで詳細に把握できる装置を開発した。この装 置により不織布が変形を受けた時、内部の繊維配向、接着 点ひずみなどの変化を知ることができることを示した ${ }^{26)}$ 。

Mitra らは、ポリプロピレン繊維ニードルパンチ不織布 の構造パラメータ(繊維数指数 (INF) と繊維配向) と引張試 験における破壊荷重 $(\mathrm{F})$ 、破壊伸度 $(\mathrm{E})$ および横縮み (poisson 比：P 比)との関係を研究し、INF が高いほど $\mathrm{F}$ および $\mathrm{P}$ 比が高く、Eが低い、また、横方向繊維配向度 が高いほど Fと P 比が低く、Eが高いことなどを示した ${ }^{27) 。 ~}$

Lasicは、ステッチボンド不織布のバイアス方向の引張 試験を行い、いずれの角分布についても破断強度は Gauss 関数に従うことを示した ${ }^{28)}$ 。

$\operatorname{Kim}$ らは、ポリプロピレン繊維の熱接着式不織布の引 張変形中の構造変化を観察する新しい装置を開発した。本 装置により、繊維配向分散関数 (ODF)、結合領域のひず み、単位セルのひずみ等の変形パラメータを計測し、その 解析の結果、繊維 ODF は引張特性に大きく影響すること を明らかにした年)。また、彼らは、不織布の加工条件(カ レンダー温度など)に起因する構造特性(纎維配向、接着点 など)と縦方向、横方向および 34 度方向での引張特性の関 係を本装置を用いて解析した ${ }^{303}$ 。

Patelらは、スパンボンドのニードルパンチ不織布 $(\mathrm{A}) 、$ スパンボンドの熱接着不織布 $(\mathrm{B})$ およびステープルファイ バのニードルパンチ不織布 $(\mathrm{C})$ の応力一歪挙動を解析する ために、㵶維の回路網理論を適応した。B 不織布は理論值 と実験值が良く一致し、C 不織布の理論応力一歪曲線は実 験曲線から大きく逸脱し、A 不織布はわずかに逸脱するこ とを示した ${ }^{31 !}$ 。また、通常幅の引張試験法(X 法)と幅広の 試験法(Y 法)の結果、A 不織布の初期弾性率はX 法の方が $\mathrm{Y}$ 法より著しく低いが、B 不織布はほとんど同程度である ことを示した ${ }^{32 ! 。}$

渡邊らは、ニードルパンチ不織布における針の繊維把持 本数、買通力、繊維の絡み合いの大きさを測定し，それら と不織布の引張強力との関係を数種類の針について比較検 討した。針の繊維把持本数は、貝通力、纎維の絡み合いの 大きさと高い相関があるが、把持本数が 20 本以上になる と、ウェブの構造が破壊されて良い不職布ができなく、1 つのスロートの把持繊維本数は 7 本程度が最適あると結論 した ${ }^{333}$ 。

Ghassmieh らは、レーヨン/ポリエステル混合繊維を原 料とする水流交絡法不織布について、その微細構造特性を 決定する繊維配向およびストレートセグメント長の分布を SEM 観察と画像分析によって㬰測し、レーヨン比率、ウェ ブ配向 (直交、平行)、噴射回数扣よび噴射面角度が、繊維 配向角分布、引張強度および弾性率に及ぼす影響について 研究した

Xuは、アラミド、ガラスおよび炭素繊維不織布の画像 にHough 変換法(HT法)による画像解析を行い、不織布 内の繊維配向分布とゼロスパン引張強度との関係を考察し た ${ }^{3.5)}$

\section{4 その他(吸音、透過、吸水、断熱など)}

Hoshani らは、不織布の騒音抑制材の広範囲な応用に関 連して、Zwikker-Kosten 理論(音響性能の数值計算)から 誘導した数学モデルを用いて、多孔質中の音波の伝搬を検 討した。特に、繊維ウェブの厚みと間隙率の峦化に対する 
繊維ウェブの吸音係数を算出し、アクリル繊維、綿、ポリ エステル繊維の不織布に関して、計算値と実測値が比較的 良く一致することを示しだ○门。

Haase らは、織物と不織布から構成される接着布の燃焼 性は、不織布の構造、燃焼方向、密度の影響を大きく受け ることを示しだ7?。

Sengupta らは、黄麻 $(\mathrm{J})$ おび化学的に加工した黄麻 (YJ) とポリプロピレン繊維 $(\mathrm{PP})$ との混繊ニードルパンチ 不織布について、空気透過性と不織布の製造条件 (混合萃、 パンチ密度、針貫通深さ、黄麻繊維長、布厚さ、布密度) との関係を研究した ${ }^{381}$ 。

Jirskらは、ポリエステル繊維 $75 \%$ とポリエステルバイ コンポーネント繊維 $25 \%$ の混合ウェブを原料とし、ウェ ブ直角配列(PLN)とウェブ交差配列 (CLN)のかさ高性不織 布の断熱特性を比較検討した。PLNはCLNよりも圧縮抵 抗率が高いため、任意の圧縮力に対して高い断熱特性を維 持すること、不織布を圧縮するほど熱伝導率は減少し、繊 維自身の熱伝導率に近づくこと、繊度が太いほど圧縮下で の熱抵抗が高いことなどを示しだ9”。

Koehler らは、亜麻繊維/ポリプロピレン纎維混紡ウェ ブのニードルフェルトの諸性質に及ぼす生産条件の影響に ついて研究しだ0)。

Homonoff は、高吸水生繊維 (SAF) から作られたニード ルパンチ不織布の構造及び一般的な特性、衣服、医療用品 等の応用等について詳細に検討した"1!。

梶原らは、不織アルミニウム綫維層(WAFL)の有効熱伝 導率特性を明らかにしだ2?

\section{5 予測および設計}

Barkerは、最終形状と寸法制御が特に重要である自動 車の内装用ニードルパンチ不織布部品の限界寸法を正確に 測定するシステムを開発した ${ }^{43)}$ 。

Tsai は、不織布の透過率、細孔径、万過効率に関する 計算式(繊維径、充填密度の関数：A 式) および力学強度に 関する計算式(単繊維弾性率、緎維配向角分布の関数：B 式)の理論的誘導を行い、計算值と実験値と比較検討した。 $\mathrm{A}$ 式は、メルトブローン不織布の場合良く実測値と一致し たが、ニードルパンチ不織布の場合、透過率は実測值の方 が低かった。B式は両不織布で良く一致したと報告してい $る^{(4)}$ 。

Kothari らは、熱接合およびニードルパンチ不織布のク リープ挙動を予測するため、構成繊維のネットワーク構造 を考慮した理論式を提案した。クリープ挙動の理論的予測 はこの式からできるけ机ども、熱接合およびニードルパン 千不織布の実測曲線は、残念ながら理論曲線から離れた 渡邊らは、Van Wyk の瀻維集合体の圧縮理論(6)をニード ルパンチ不織布の圧縮に適応できるように压縮による繊維 の交錯点間距離の変化を考慮して理論を発展させ、不織布 の圧縮曲線を予測でをる推定式を提案しだ7。また、針の スロートの形状を三角錐と仮定し，スロートに把持される
繊維本数を推定する計算式を提案し、12 種類の針につい て計算値と実測值を比較検討した結果、両者の値は良く一 致した。また、針による厚さ方向に配列する繊維の割合を 検討した結果、1つのスロートに把持される繊維本数は 7 本程度が最適であると報告している(8)。

\section{6 宇宙用材料への応用}

宇宙用不織布は、特殊な極限状態の環境下で使用される ため、特異性能が要求される。

坂部らは、370 1200 $\mathrm{C}$ に加熱さ机るスペースシャトル などの宇宙往復機熱防護システム、特にひずみ緩衝材への 不織布の適用を検討した。耐熱アラミド繊維を原料とし、 通常の不織布製品には要求さ机ない特殊な性能、例えば高 温における不織布の引張強度や撥水性、アウトガス特性、 断熱性などを研究した

Tang らは、宇宙および惑星上の真空環境での船外活動 (EVA) 用の宇宙服に用いられる不織布の断熱材料としての 特性を研究した。低高度軌道の高い真空条件 $\left(10^{-5}\right.$ torr $)$ 、 中間的真空条件 (10 $0^{-3}$ torr)、および火星表面の真空条件 (8 torr)のそれぞれの環境下で実験を行い、熱伝導特性を評 価した ${ }^{50)}$ 。

\section{4. まとめ}

最近の報告では、他の材料との複合化あるいは積層され た不織布、および高強度・高弾性、耐熱性などの高機能性 繊維不織布、ポリ乳酸などの生分解性㵶維不織布に関する 論文が多かった。しかしながら、生分解性繊維の不織布の 紹介は、紙面の関係で割愛させていただいた。今後、さら なる新機能性不織布の開発・応用が期待される。

\section{参考文献}

1）西川文子良、繊機誌(繊維工学)、55, 234-236(2002).

2）鈴木龍雄、繊機誌(繊維工学)、55, 228-230(2002).

3）通商産業省生産動態統計調查 (1999).

4) P. K. Ganguly, S. Sengupta, and S. Samajpati, Indian J. Fiber Text. Res., 22, 169-175(1997).

5）渡邊 明、横井輝之、三輪 實、繊維学会予稿集, 1999 (G) , 156 (1999).

6) A. Watanabe, M. Miwa, and T. Yokoi, Text. Res. J., 70, 402-408(2000).

7) 三輪敏宏、渡邊 明、横井輝之、三輪 實、繊維学会 予稿集，55,261(2000).

8）三輪钽宏、渡㣎 明、横井輝之、三輪 實、繊維学会 予稿集，56,305(2001).

9）深谷賢志、渡邊 明、横井輝之、三輪 實、繊維学会 予稿集，57,221(2001).

10）立松宽之、渡䢩 明、横井輝之、三輪 實、繊維学会 予稿集，55, 262(2000).

11) C. R. Debnath and A. N. Roy, Indian Text. J., 110, 50-53 (1999). 
12) S. LEE, 小野村貫治、木村 誠、野口博司, S. CHEONG, 日本機械学会材料力学講演会講演論文集, 407-408 (1999).

13) P. K. Ganguly and S. Semgupta, Indian J Fiber-Text. Res., 24, 34-40 (1999).

14) S. H. Lee and T. J. Kang, J. Compos. Mater, 34, 816-840 (2000).

15) G. Wizemann, Tech. Text., 43, 20-22(2000).

16) B. Pourdehyhimi, R. Dent, A. Jerbi, S. Tanaka and A. Deshoande, Text. Res. J., 69, 185-192(1999).

17) B. Pourdehyhimi and Ntr, Text, Res. J. 69, 233-236 (1999).

18) I. Krucinska and S. Krucinski, Text. Res. J., 69, 363-369 (1999).

19）金子純一、高寺政行、清水義雄, 繊維学会予稿集 $G, 63$ (1999).

20) T. Kang and S. H. Lee, J. Compos. Mater, 33, 2116-2132 (1999).

21) F. Thorr, J. Y. Drean, and D. Adolphe, Text. Res. J., 69, 162-268(1998).

22) A. Barella, Text. Res. J., 70, 277(2000).

23）永田紳一、川北嘉洋、小山清人、繊維学会予稿集， $G$, 307(1998).

24) S. Adanur and Liao, Text. Res. J., 69, 816-824(1999).

25）森沢 純、林 幸男、沢村淳二、近森麻矢、矢井田修, 機能紙研究会誌，38,55-61(1999).

26) H. S. Kim, A. Deshpande, and B. Pourdeyhimi, Text. Res. J., 71, 157-164(2001).

27) A. Mitra, M. Cybulska, and B. C. Goswami, TAPPI Proc. Nonwovens Conf., 283-293(1999).

28) V. Lasic and M. V. Bottteri, J. Text. Inst., 91, 324-332 (2000).

29) H. S. Kim and B. Pourdeyhimi, Text. Asia, 32, 51-56 (2001).

30) H. S. Kim, B. Pourdeyhimi, A. S. Abhiraman, and P. Desai, TAPPI Proc. Nonwovens Conf., 2000, 38(2000).
31) P. C. Patel and V. K. Kothariv, Indian J. Fibre Text. Res., 26, 398-402(2001).

32) P. C. Patel and V. K. Kothari, Indian J. Fibre Text. Res., 26, 409-413(2001).

33）立松寛之、渡邉 明、横井輝之、三輪 實、繊維学会 予稿集 56, No.1, 307(2001).

34) E. Ghassmieh, H. Rsteeg, and M. Acar, TAPPI Proc. Nonwovens Conf., 42(2000).

35) B. Xu, TAPPI Proc. Nonwovens Conf., 43(2000).

36) Y. Houshani and Y. Yakubov, Text. Res. J., 69, 519-526 (1999).

37) J. Haase and H. Mehlhorn, Tech. Text., 42, 289-290 (1999).

38) S. Sengupta, S. Samajpati, and P. K. Ganguly, Indian J. Fibre Text. Res., 24, 103-110(1999).

39) O. Jirsk and U. T. G. Sadikogl, Text. Res. J., 70, 121-128 (2000).

40) E. Koehler, A. Bergner, and S. Odenwald, Tech. Text., 43, 25-26(2000).

41) E. Homonoff, Text. Asia, 31, 45-47(2000).

42）梶原征洋、吉木裕也、日本伝熱シンポジゥム講演論文 集、38, 519-520(2001)

43) J. R. Barker, Pap. Am. Soc. Mech. Eng., 5(1999).

44) P. P. Tsai, TAPPI Proc. Nonwovens Conf., 37 (2000).

45) V. K. Kothari and P. C. Patel, Indian J. Fibre Text. Res., 26, 273-279(2001).

46) C. M. Van Wyk, J. Text. Inst., 37, T285-292(1946).

47）内藤隆文、渡邉 明、横井輝之、三輪 實、繊維学会 予稿集、56,306(2001).

48）立松宽之、渡邊 明、横井輝之、三輪 實、繊維学会 予稿集、57, 220(2002).

49）坂部敦彦、安藤則雄、稲田一英、繊機誌、53，44-51 (2000).

50) E. S. Orndoff and L. A. Trevino, SAE. Tech. Pap. Ser., (Soc. Automot Eng.) 10(2001).

\section{第 6 回 CPD(一般共通課題)講演会}

主 催：日本繊維技術士センター 共 催：日本技術士会近畿支部

日 時：平成 15 年 5 月 16 日(金) $13: 30 \sim 16: 30$

場 所：大阪産業創造館 (中央区本町 1-4-5 TEL:06-6264-9800) 6 階 E 会議室

(地下鉄 堺筋本町駅 出口(1)(2) (12)(13)本町通り東へ約 300m、北側

CPD 区分 A、課題 1、時間 3.0 です(CPD 手帳を抢持ち下さい)

演題及び講師：CPD 活動の 1 年を振り返って 技術者倫理について $(2)$

日本繊維技術士センター 常務理事 松尾 達樹 日本繊維技術士センター 常務理事 小林 宏臣

参加申込等の詳細は下記にお問合せ下さい

日本繊維技術士センター(JTCC) 事務所テ564-0062 吹田市垂水町 3-7-18(P\&M ビル 5F)

TEL : 06-6339-1237、FAX : 06-6339-0337 